\title{
Competency profile for librarians teaching information literacy
}

\author{
D.N.S. Selematsela' \\ Centre for Information and Knowledge Management, University of Johannesburg, \\ PO Box 524, Auckland Park 2006, South Africa \\ Tel: 27 |2 48| 423| \\ daisys@nrf.ac.za \\ and \\ A.S.A. du Toit ${ }^{2}$ \\ Centre for Information and Knowledge Management, University of Johannesburg, \\ PO Box 524, Auckland Park 2006, South Africa \\ Tel: 27 I| 4892186 \\ adutoit@uj.ac.za
}

\begin{abstract}
Received: $30^{\text {th }}$ November 2006
Accepted $: 7^{\text {th }}$ May 2007

South African academic libraries are starting to pay attention to the role played by instruction librarians. There is an acknowledgement that librarians as 'educators' need to learn how to teach information literacy skills. Instruction librarians are either not trained educators or do not have a pedagogical background. Many instruction librarians were placed in, or found themselves, assuming a teaching role with regard to information literacy instruction, and subsequently refined their craft while on the job. The motivation for this research was that librarians as 'educators' are faced with challenges that impact on their teaching role. The research was carried out in two parts: a literature survey and an empirical investigation. The investigation was confined to academic libraries that have an instruction librarian who facilitates information literacy skills instruction. The findings of the research were supportive of the objective that there is a serious need to have understanding, knowledge and skills regarding the dynamics involved in the teaching of information literacy skills, in order to make the program a success. The authors propose a competency framework for implementation as a management tool for designing key performance areas for instruction librarians.
\end{abstract}

\section{Introduction}

According to LaGuardia (2001:2-6) instruction librarians are made, they are not born with teaching skills. Many instruction librarians are placed, or find themselves, in the instruction field because no one else wants to teach information literacy. In support of LaGuardia, Tuttle (200I:I4I) maintains that the "majority of librarians received little or no training in graduate school and have learned and refined the craft on the job". Library instruction experience and skills have only recently begun to be routinely included as a requirement in library position advertisements, and still show up mainly in the desirable qualifications category rather than as a requirement. Instructional expertise is an add-on feature for most job advertisements. The library and information services are starting to pay some attention to instruction librarians, seemingly acknowledging that information professionals need to learn how to teach information literacy skills. This was made evident by a significant number of librarians represented at the Library and Information Association of South Africa (LIASA), 200 I workshop on information literacy (De Jager and Nassimbeni:2003 I I0).

According to LaGuardia (200I:I), there is a substantial need for good library instruction in all libraries. Good library instruction can overcome flaws and faults in a library. According to LaGuardia (2001:6) the transfer of teaching expertise to librarians, whose strength is not teaching, is complicated by the instruction librarian's anxiety and fear of appearing incompetent in the subject matter. Instruction librarians require a specialized set of skills such as mastering the teaching techniques of preparation and presentation that can be applied in a variety of classes across disciplines, and in both designing and teaching the use of new programs and technologies (Gunter 2001:94-95). This empathy and fear of being involved with training initiatives is enforced by a lack of institutional support, especially the continuous development and encouragement of instruction librarians.

Instruction librarians find themselves thrown in at the deep end as they do not understand, or they lack knowledge of the educational theories and methodologies that can be applied to information literacy instruction. The main challenge observed by Oberman (2002:5) is that the learning of library instruction and information literacy programs is intertwined

I. Daisy N.S. Selematsela is a Knowledge Manager, National Research Foundation, South Africa

2. Adeline S.A. du Toit* is Professor and Chair, Centre for Information and Knowledge Management, University of Johannesburg, South Africa 
with socioeconomic, political and cultural differences, and librarians are not in a position nor trained to handle such issues. There is less focus on the ongoing professional development of librarians as teachers. Librarians learn to teach by experience and expected to have a working knowledge of the concepts that underscore pedagogy. Instruction librarians do not know how to fill this role as 'educators', pedagogy and learning theory is not part of the library and information science curricular (Oberman 2002:5).

The objective of this article is to determine if instruction librarians have the knowledge and skills to make information literacy programs a success. The problem that will be addressed is: Can the development of a competency framework for instruction librarians improve the competencies required in information literacy instruction?

\section{Instruction librarian challenges}

The information literacy concept is perceived to prepare students for lifelong engagement in an information literate community and in the general information society. What librarians seek in instruction sessions is to bring about learning in students. Learning implies a change from a previous behaviour to a different one, from a previous belief to a new one and from a previous way of thinking to a new one. This mindset places additional demands on instruction librarians as teachers. This teaching role provides them with an opportunity to demonstrate an information literacy approach to life. The challenge, therefore, is to use teaching methods and approaches that model information literacy practices (Hinchliffe 2002:95).

Information communication technology (ICT) has inducted the library into the electronic information age. However, models of information literacy instruction service delivery have not changed. Librarians tend to cling to the old ways, this manifests itself firstly, in the familiarity with specific tools and techniques, and secondly, in the assumption that instruction librarians seem to know that library instruction is good for learners, whether the learners want it or not (Herrington 1998:382-383).

Instruction librarians are faced with the challenge of undergoing cognitive and behavioural changes within themselves. These changes affect students' perceptions of information literacy instruction and their performance in the information literacy session. Librarians should have an understanding of the institutions programs of study, as this is the foundation for designing content and the teaching of information literacy programs (Nations-Johnson 1993: 142).

Oberman (2002:2) noted that instruction librarians should be aware of and sensitive towards the teaching philosophies of their institutions. Partello (2005:1 10), who wrote from her experience as an instruction librarian, found that the benefits of teaching information literacy, is the opportunity to be aware of the students limitations and needs. Based on these cognitive challenges, the following behavioural changes gleaned from a literature review are recommended for instruction librarians:

\section{Culturally diverse instruction sessions}

Hadaway (1993:61-62) maintains that instruction librarians as teachers are human beings who bring their cultural perspectives, prejudices, stereotypes, misconceptions, values, hopes and dreams to the information literacy instruction session. Hadaway cautions that values and perspectives may mediate and influence the way messages are communicated and perceived by the learners. Instruction librarians must examine their own backgrounds and experiences to determine what values and attitudes they may bring into the instruction session and also to realize that "their way" is not the only way when facilitating in a culturally diverse environment. Contech (2003:2) agrees with Hadaway and is of the opinion that, as members of social and cultural groups, instruction librarians' attitudes and preferences contribute to the theories which are brought to the instruction role.

\section{Language}

Ethnic and linguistic diversity is already a dominant feature of academic institutions, especially in South Africa. Instruction librarians should examine and challenge the attitudes, values and beliefs that drive their current practices with diverse students. Library instruction should accommodate students' language characteristics, including the language use patterns, language preferences and language proficiency. In the case of students whose primary language is not English, the instructor needs to use language flexibly in order to accommodate the students. Instruction librarians need to match the language of instruction to the proficiency characteristics of the students (Cloud 1993:82-84).

Culture

Cloud (1993:64) asserts that culture has various dimensions which affect students. There are surface or external dimensions that manifest in language, dress, customs and family composition. The internal dimension is manifested in values, beliefs, attitudes and norms.

Trueba in Cloud (1993:64) argues that cultural knowledge and cultural values are at the basis of reasoning, inferring and interpreting meanings, hence the academic environment and the organization of library instruction sessions "must 
acknowledge and respond to the cultures of its students in order to maximize participation in learning activities". Students bring to the library instruction sessions diverse background experiences and knowledge bases. However, instruction librarians rarely investigate their students' values, background knowledge and experience when shaping instruction (Cloud 1993:64). This drawback may be attributed to librarians' training and Library and Information Science curricula.

Instruction librarians need to understand the socio-cultural context of learning, so that they can modify it for the benefit of the students they serve and to achieve maximum benefit from their teaching efforts (Cloud 1993:66). In addition to previous experience, the belief system and disciplinary traditions that students bring to academic institutions should be considered in library instruction activities, as they may have an impact on the learning process (De Jager \& Nassimbeni 2003:108).

\section{Facilitator talk time}

Nations-Johnson (1993:144) asserts that the average teacher's time for talking occupies 75 percent of class time. In a study to assess learner performance during class dialogue sessions, it was observed that discussions, in which talk time was reduced to approximately 50 percent, were more responsive to learner needs and more successful in directing discussion. Nations-Johnson (1993:145) points out that the aim of responsive facilitation is to maintain a balance between observation, listening and responding to the learners.

Properly balance and sequence literal and figurative questions

The contact mode of delivering information literacy instruction sessions to 30 or more learners is much more demanding especially if responsive facilitation or discussion is used. Response facilitation requires exceptional effort from the instruction librarian (Nations-Johnson 1993:150).

Nations-Johnson (1993:145) indicates that "if students comprehend literal information first, they can better respond to figurative questions". Literal figurative questions should be presented in a balanced, carefully sequenced fashion. The instructor should also refine his or her question-asking technique.

Facilitator and learner interruption

Nations-Johnson (1993:145-146) maintains that an important condition for successful dialogue is the observance of dialogue protocol, which prohibits verbal interruptions. Interruption by both facilitator and learner can become intrusive. Facilitators should become a model of appropriate turn-taking. Facilitators should make a conscious and conscientious effort to listen, and allow learners to complete their thoughts before speaking.

Question-asking technique

When learners are confused during the instruction session, the facilitator must rephrase questions, rather than simply repeating them. It is important for the facilitator to pause before, between and after questions. The pausing process enhances the facilitator's ability to formulate questions, and gives the learners time to comprehend the content of questions and time to respond. Pausing gives the student the impression that their participation during the sessions is valued and also that their own participation is regarded positively (Nations-Johnson 1993:146).

\section{Performance}

The facilitator needs to identify the learner's literacy needs, assist the performance of learners who did not understand and solicit the help of learners who did understand to assist their peers. The development of responsive facilitation techniques, including the ability to assist performance and to conceptually connect learner and facilitator turns, is of benefit to both parties as individuals and members of a group (Nations-Johnson 1993: 147-149).

Reactive and proactive training

The information-seeking culture in academic libraries is such that the walk-in reference service has diminished, while the virtual traffic to the library's online resources is increasing (Tenopir 2003:35). Instruction librarians need to provide both online and in-person instruction in search techniques, web evaluation, and the best resources for specific subjects. Webbased teaching modules and interactive tutorials should be designed to match today's learner study habits (Tenopir 2003:36). These trends call for an aggressive information literacy teaching program, which may take the form of either a reactive training program or a proactive training program approach. In reactive training, the instruction librarian invites the academic department to contact the library to make arrangements for a lecture or hands-on presentation. Proactive training is when the librarian takes the initiative to aggressively promote what the library believes is essential for learners to know in order to be information literate (Tenopir 2003:36).

Presentation formats: lecture, online tutorial and hands-on instruction

With an electronic format combining lecture and hands-on presentations during instruction, instruction librarians face the challenge of the diversity of skills and differences in learning preferences (that is, active versus passive learners) in the 
classroom. The instructor finds it difficult to keep the entire class at the same pace and interested in a hands-on presentation or lecture. A common scenario is that technically skilled students get bored waiting for the less technical students struggling with, for example, mouse navigation. To pass time, technically skilled students tend to read e-mails, surf the Web, or distract their neighbour and interrupt the instructor requiring individual attention, while the less technically skilled students have difficulty keeping up (Cudiner \& Harmon 200 I:49-5I).

Where the lecture format is used as a training method, there is a higher retention of concepts. By contrast, the online tutorial and guided hands-on lead to a higher retention of mechanical skills. The hands-on approach to instruction requires more resources and instructor's time for coaching. However, a combination of presentation methods is a worthy investment as it encourages students to adopt self-reliant search behaviours, develop a positive attitude and a strong motivation for students to continue to learn and practice their skills on their own (Ren 2000:323-327).

\section{Motivation}

The instruction librarian is faced with the challenge to motivate students during instruction. The instructor's knowledge and understanding of what motivates students and how they learn, is essential to teaching critical thinking skills to library users. Information literacy skills stimulate intellectual curiosity, encourage information-seeking and exploration behaviours and promote a passion for lifelong learning. This can be achieved through the use of active learning strategies during instruction (Small, Zakaria \& El-Figuigui 2004:97-98). Small et al maintain that for instructors to stimulate student motivation, active learning strategies must be included in the instruction process to facilitate student participation and interaction.

\section{Setting the tone}

Student anxieties about using the library, as well as the instruction librarian's teaching anxieties, play a role in the success or failure of the information literacy session. Instruction librarians should be aware of these anxieties and attitudes students bring to the information literacy session (Oswald and Turnage 2000:347). The students' attitude toward library instruction is related to the perceived interest, enthusiasm and support of the instructor. Oswald and Turnage (2000:348) points out that an effective approach to setting the tone for instruction involves dressing in a professional manner, being organized and practicing the presentation. The training facility, handouts and materials needed for instruction, must be prepared in advance. Contact and body language must be positive. Contact with students and the display of enthusiasm about the subject is perceived to carry the students along during instruction (Oswald \& Turnage 2000: 350).

\section{Student concerns}

According to Ward (2001:923), information literacy instruction should begin and end with student concerns. Instructors should make an effort to focus on topics that mean something to the students. Students learn research better within meaningful contexts. Rather than assigning a generic topic where students will practice a skill in finding information on the topic, but experience little meaningful learning because they do not understand how the issue relate to the larger world, Ward concludes that instruction librarians should take time to understand students, as student's issues are real-world issues.

\section{Challenge the unquestioned}

Students are not information literate if they simply accept at face value the news they receive in the media or find on the Web. The conception of information literacy instruction should be focused on critical thinking. An opportunity during instruction could be provided to generate meaningful connections between the research topic and the lives of students, or to help students question the nature of discourse that takes place (Ward 2001:924).

\section{Relevance}

Heery and Morgan in Stubley (2002:34) assert the need for relevance in library instruction sessions. According to them relevance is easier to achieve in subject-oriented sessions and possibilities do exist for improving relevance when taking the generic approach. The notion that library instruction has to be timely, relevant and engage the advent of the virtual learning environment has to be promoted during instruction (Moore \& Abson 2002:34).

\section{"Point of need"}

The problem with current methods of library instruction is that the learner is unable to transfer knowledge gained from one library instruction to the needs of other course/module assignments (Herrington 1998:383). According to Moore \& Abson (2002:35), there is the challenge of ensuring that information skills teaching is delivered to students at the point in their studies that will be most of use to them; Instruction should be provided at the time learners begin to look and need to use the information. Students want to learn in the context of the subject. Moore \& Abson (2002:35) conclude that instruction librarians cannot do that, but can help the faculty prepare for that by integrating the library into coursework. 
Information literacy skills

Herrington (1998:384) maintains that information literacy concepts should be built into the library system Information sources of all formats should be linked by subject and the user guided from general to specific sources. Basic instruction on search techniques, including Boolean searching, should be made available on the library system

Search engines to access digital collections

Even though learners might have basic computer access skills before they come to the library, an information seeker in a digital library environment needs a lot of initial training and constant hand-holding. According to Hope, Kajinara and Liu $(2001: 21)$, students need to learn to look for the scope of the resources available to them, and also to understand the differences between web-based databases and the public Web. These trends pose a challenge for an instruction librarian to assume the role of instructor, but this may mean instruction in computer proficiency as well as in information-seeking habits. The digital library user needs to be trained on the requisite equipment needed for accessing digital collections.

Online tutorials may be used as another avenue to provide guidance to the digital library user. Instruction librarians have, firstly the challenge of bridging the gap between synchronous learning associated with the traditional models and methods of information transfer and developing ways to bring these synchronous learning features into the asynchronous learning environment associated with the digital age (Hope et al 200I:20). Secondly, with instruction in digital resources, instruction librarians should consider whether there are enough internet terminals in the library to handle the increase in use, as learners are encouraged to view multimedia digital collections (Kibirige \& DePalo 200 I:28I-292).

User independence

According to Herrington (1998:383) the objective of library instruction as proclaimed by the American Library Association (ALA) Conference of 198I, was that of user independence and self-help. Instruction librarians need to focus on helping the user become more independent in locating and retrieving information. Self-help is regarded as the preferred method of instruction over handouts and workshops.

\section{Outreach projects}

To enhance the learning experience of all students and to reach the goal of making the library less intimidating to students just out of school, instruction librarians should engage in outreach efforts that, according to Kraemer, Keyse and Lombardo (2003:6) will also reach patrons outside the library. Effective outreach takes into account the information needs of the student as well as the potential barriers that may inhibit learning. For example, students with special needs such as physical and learning disabilities require individual services and support that they cannot obtain in a one-shot library instruction session.

The library outreach activity could include a liaison relationship between librarians and academic departments. The purpose of the liaison program is to facilitate communication, promote library instruction and other library services and resources, and to expand library's instructional efforts through the development of subject-based instruction sessions for individual courses (Johnson, McCord \& Walter 2003:21; Kraemer et al 2003:7).

\section{Methodology}

The purpose of the empirical survey was to measure the opinions of instruction librarians on the required competencies in the emerging field of information literacy skills instruction. The survey population comprised instruction librarians from nine academic libraries affiliated to the Gauteng and Environs Library Consortium (GAELIC). The survey instrument was an online questionnaire which was e-mailed to the sample population. The questionnaire comprised twenty four questions. A preliminary draft of the questionnaire was tested before the instrument was considered sufficiently reliable for distribution. A week prior to the electronic mailing of the questionnaire, a draft questionnaire was administered to I4 subjects as a pre-test with the aim of refining the survey instrument. As a result of comments relating to ambiguity, several questions were modified. Questions were clustered according to categories including the explanation in the use of instructions to answer the questions.

The questionnaire was e-mailed to 67 information literacy librarians in the nine academic libraries. with a return deadline date set for approximately one week. After the deadline expired, a follow-up survey was e-mailed to librarians who had not returned the questionnaire by the deadline date. After two follow-up exercises were initiated, a total of 43 questionnaires were returned of which one was rejected due to insufficient data. The final response rate was $64, . .18 \%$ which represented 42 completed questionnaires.

\section{Findings}

Biographical details

In terms of the category "highest qualification in any field", 40,5\% (I7) had Honours degree in any subject field; 3I,0\% (13) had Masters degrees in a field other than Library and Information Science and 16,7\% (7) had Bachelors degrees. In 
terms of the category "highest qualification in Information science", $37,5 \%$ (I5) indicated that they had an Honours degree, 25,0\% (10) had a Masters degree and 20,0\% (8) had a Bachelors qualification in Library or Information Science. These findings suggest that librarians to some extent prefer to have an Honours or Masters degree in any subject field in order to have subject expertise, rather than to follow the traditional Library and Information Science curriculum..

The number of years experience in information literacy instruction showed that $35 \%$ (14) had more than ten years, $32,5 \%$ (13)had experience between six to ten years, followed by $22,5 \%(9)$ of between one to five years experience. This suggests that librarians are involved in information literacy instruction even though they lack the teaching methodologies and can raise awareness of what they are involved in as professionals. The other inference is that there is a need for the role of an instruction librarian and academic library employers are aware of the need to training students in information literacy skills.

Qualities an instruction librarian should display

The majority of the respondents, $65,9 \%$ (27), indicated that in their experience, students prefer an instruction librarian who is a teacher they can rely on for future reference. Similarly, 58,5\% (24) indicated that students prefer an expert to depend on or an advisor 18 (43,9\%). Only $29,3 \%$ (12) of the respondents indicated that students prefer a mentor who is not pushy. The results therefore indicate that a student wants to be 'mentored' throughout the process.

Components of information literacy

Since the importance of being informed about the institution's teaching and learning strategy is critical in information literacy instruction, $73,8 \%(3 \mathrm{I})$ of the respondents viewed the understanding thereof to be very important. In response to the question "the need to engage in critical reflection of viewing information literacy as a holistic educational outcome based on transferable concepts and skills", $64,3 \%$ (27) of the respondents viewed it to be very important. In response to the question "an understanding of students academic requirements facilitated by study guides and the online learning environment" were regarded by $57,1 \%(24)$ of the respondents as very important.

The results indicated differences in frequency in the components of information literacy that an instruction librarian must have the knowledge and understanding thereof. Learning implies a change of behaviour and belief. Therefore, the challenge for instruction librarians is to use teaching methods and approaches that model information literacy practices. The findings are consistent with Hinchliffe's (2002:96) statement that instruction librarians need to understand who the students are, become critical and cautious thinkers, and engage in campus teaching events.

As illustrated by Table I, an overwhelming 88, I\% (37) of the respondents indicated that instruction librarians need the capability to develop, deliver and evaluate information literacy programs, while the ability to integrate new electronic formats into the information literacy programs was regarded as very important by $56,1 \%(23)$ of the respondents.

Table I Capabilities required by an instruction librarian

\begin{tabular}{|c|c|c|c|c|c|c|}
\hline & & Not important & Somewhat important & Important & Very important & Total \\
\hline \multirow{2}{*}{$\begin{array}{l}\text { Capability to develop, deliver } \\
\text { and evaluate information } \\
\text { literacy programs }\end{array}$} & Count & & 3 & 2 & 37 & 42 \\
\hline & $\%$ & & $7,1 \%$ & $4,8 \%$ & $88,1 \%$ & $100 \%$ \\
\hline \multirow{2}{*}{$\begin{array}{l}\text { Ability to integrate new } \\
\text { electronic formats into the } \\
\text { information literacy } \\
\text { programs }\end{array}$} & Count & 3 & 5 & 10 & 23 & 41 \\
\hline & $\%$ & $7,3 \%$ & $12,2 \%$ & $24,4 \%$ & $56,1 \%$ & $100 \%$ \\
\hline \multirow{2}{*}{$\begin{array}{l}\text { Ability to design electronic } \\
\text { instructional materials }\end{array}$} & Count & 2 & 10 & 9 & 21 & 42 \\
\hline & $\%$ & $4,8 \%$ & $23,8 \%$ & $21,4 \%$ & $50,0 \%$ & $100 \%$ \\
\hline \multirow{2}{*}{$\begin{array}{l}\text { Ability to design print } \\
\text { instructional materials }\end{array}$} & Count & 4 & 6 & 10 & 22 & 42 \\
\hline & $\%$ & $9,5 \%$ & $14,3 \%$ & $23,8 \%$ & $52,4 \%$ & $100 \%$ \\
\hline
\end{tabular}

It is inferred from the findings that instruction librarians require training and development programs that would teach them how to actually design information literacy course materials in either print or online mode. The inference is that librarians have the capability to develop, design and evaluate learning materials collaboratively and get involved in the actual delivery of materials, however, there is a need for the knowledge and understanding of the processes of materials development and design (Inglis 2003:247). 
Understanding of different learning styles

There were observed differences in relation to the effectiveness of the instruction librarian's role that require an understanding [replace 'knowledge' in this section] of different learning styles and familiarity with a variety of teaching methods. The majority of the respondents $(61,9 \% ; 26)$ indicated that knowledge of group teaching is very important for instruction librarians, while $47,6 \%$ (20) regarded knowledge of facilitating as very important. Knowledge of coaching is very important to $33,3 \%$ (14) of the respondents and $43,6 \%$ (I7) of the respondents regarded knowledge of learning contracts as a teaching method as important.

A reason why group teaching was considered very positively, might be that group teaching is the only teaching format instruction librarians are familiar with, as they might lack the necessary knowledge and skills in understanding the context and processes in which learning takes place (Morrison et al.2003:214)..

\section{Experiences required}

Respondents indicated that considerable experience was very important in database searching $(73,2 \%)(30)$, resources in electronic formats (78\%) (32), internet searching (68,3\%) (28) and computer literacy $(53,7 \%)$ (22). This is consistent with the findings of Stroyan (2000:40), Kaufman (2004:4I) and Hope et al (200I:7) that students expect to find everything online, even the less experienced internet searchers have high expectations of finding information easily and quickly. The assumption is that skills and knowledge of computer software and hardware are considered to have an influence in the facilitation of the training programs.

Non-technical competencies

Table 2 outlines the non-technical competencies instruction librarians thought they should have.

Table 2 Non-technical competencies required

\begin{tabular}{|c|c|c|c|c|c|c|}
\hline & & Not important & Somewhat important & Important & Very important & Total \\
\hline \multirow[t]{2}{*}{ Teaching skills } & Count & 2 & & 10 & 30 & 42 \\
\hline & $\%$ & $4,8 \%$ & & $23,8 \%$ & $71,4 \%$ & $100 \%$ \\
\hline \multirow[t]{2}{*}{ Critical thought } & Count & & 3 & 11 & 25 & 39 \\
\hline & $\%$ & & $7,7 \%$ & $28,2 \%$ & $64,1 \%$ & $100 \%$ \\
\hline \multirow[t]{2}{*}{ Analytical thinking } & Count & & 2 & 12 & 25 & 39 \\
\hline & $\%$ & & $5,1 \%$ & $30,8 \%$ & $64,1 \%$ & $100 \%$ \\
\hline \multirow[t]{2}{*}{ Organizing skills } & Count & & 1 & 15 & 26 & 42 \\
\hline & $\%$ & & $2,4 \%$ & $35,7 \%$ & $61,9 \%$ & $100 \%$ \\
\hline \multirow[t]{2}{*}{ Strategic thinking } & Count & & 3 & 13 & 22 & 38 \\
\hline & $\%$ & & $7,9 \%$ & $34,2 \%$ & $57,9 \%$ & $100 \%$ \\
\hline \multirow[t]{2}{*}{ Facilitating skills } & Count & 3 & 4 & 13 & 22 & 42 \\
\hline & $\%$ & $7,1 \%$ & $9,5 \%$ & $31,0 \%$ & $52,4 \%$ & $100 \%$ \\
\hline \multirow[t]{2}{*}{ Coaching skills } & Count & & 4 & 23 & 15 & 42 \\
\hline & $\%$ & & $9,5 \%$ & $54,8 \%$ & $35,7 \%$ & $100 \%$ \\
\hline \multirow[t]{2}{*}{ Negotiation skills } & Count & 2 & 13 & 14 & 9 & 38 \\
\hline & $\%$ & $5,3 \%$ & $34,2 \%$ & $36,8 \%$ & $23,7 \%$ & $100 \%$ \\
\hline \multirow[t]{2}{*}{ Conflict resolution skills } & Count & 5 & 14 & 16 & 4 & 39 \\
\hline & $\%$ & $12,8 \%$ & $35,9 \%$ & $41,0 \%$ & $10,3 \%$ & $100 \%$ \\
\hline
\end{tabular}

Teaching skills as a competency required by instruction librarians, was rated as very important by $71,4 \%(30)$ of the respondents. Critical thought and analytical thinking constituted two skills that were rated very important by $64,1 \%$ (25)of the respondents, and organizing skills by $61,9 \%(25)$ of the subjects. In contrast, negotiation skills $(23,7 \%)(9)$ and conflict resolutions skills $(10,3 \%)(4)$ were not rated as very important skills required by instruction librarians.

Personality attributes

Communication (language skills) (83,3\%) 35 and the ability to explain (87,5\%) 35 constituted two personality attributes required by the instruction librarian, was rated very important by the respondents (see Table 3). Students are comfortable with an instructor who is able to explain during the information literacy sessions and is sensitive to the needs of the diverse user groups. Language skills play an important role in information literacy instruction as the lesson may require the instructor to explain in a language understandable to the participants. This finding is corroborated by Cloud (1993:62-64), and De Jager and Nassimbeni (2003:106) who claim that that ethnic and linguistic diversity is a dominant feature of academic institutions. The results are summarized in Table 3: 
Table 3 Personality attributes

\begin{tabular}{|c|c|c|c|c|c|c|}
\hline & & Not important & Somewhat important & Important & Very important & Total \\
\hline \multirow[t]{2}{*}{ Ability to explain } & Count & & 1 & 4 & 35 & 40 \\
\hline & $\%$ & & $2,5 \%$ & $10,0 \%$ & $87,5 \%$ & $100 \%$ \\
\hline \multirow[t]{2}{*}{ Communication (language skills) } & Count & I & & 6 & 35 & 42 \\
\hline & $\%$ & $2,4 \%$ & & $14,3 \%$ & $83,3 \%$ & $100 \%$ \\
\hline \multirow{2}{*}{$\begin{array}{l}\text { Ability to deal with diverse user } \\
\text { groups }\end{array}$} & Count & & I & 11 & 27 & 39 \\
\hline & $\%$ & & $2,6 \%$ & $28,2 \%$ & $69,2 \%$ & $100 \%$ \\
\hline \multirow[t]{2}{*}{ Interpersonal skills } & Count & & 2 & 12 & 28 & 42 \\
\hline & $\%$ & & $4,8 \%$ & $28,6 \%$ & $66,7 \%$ & $100 \%$ \\
\hline \multirow[t]{2}{*}{ Use of presentation apparatus } & Count & 2 & 4 & 8 & 25 & 39 \\
\hline & $\%$ & $5,1 \%$ & $10,3 \%$ & $20,5 \%$ & $64,1 \%$ & $100 \%$ \\
\hline \multirow{2}{*}{ Inspire confidence in the learner } & Count & & 2 & 13 & 24 & 39 \\
\hline & $\%$ & & $5,1 \%$ & $33,3 \%$ & $61,5 \%$ & $100 \%$ \\
\hline \multirow[t]{2}{*}{ Approachable } & Count & I & & 16 & 25 & 42 \\
\hline & $\%$ & $2,4 \%$ & & $38,1 \%$ & $59,5 \%$ & $100 \%$ \\
\hline \multirow[t]{2}{*}{ Lesson planning } & Count & I & 1 & 14 & 23 & 39 \\
\hline & $\%$ & $2,6 \%$ & $2,6 \%$ & $35,9 \%$ & $59,0 \%$ & $100 \%$ \\
\hline \multirow[t]{2}{*}{ Flexibility } & Count & & 4 & 12 & 23 & 39 \\
\hline & $\%$ & & $10,3 \%$ & $30,8 \%$ & $59,0 \%$ & $100 \%$ \\
\hline \multirow{2}{*}{$\begin{array}{l}\text { Capacity for and desire to work } \\
\text { both independently and in a team }\end{array}$} & Count & & 4 & 13 & 21 & 38 \\
\hline & $\%$ & & $10,5 \%$ & $34,2 \%$ & $55,3 \%$ & 100 \\
\hline \multirow{2}{*}{$\begin{array}{l}\text { Ability to learn constantly and } \\
\text { quickly }\end{array}$} & Count & & 6 & 12 & 20 & 38 \\
\hline & $\%$ & & $15,8 \%$ & $31,6 \%$ & $52,6 \%$ & $100 \%$ \\
\hline \multirow[t]{2}{*}{ Time management } & Count & & 5 & 14 & 20 & 39 \\
\hline & $\%$ & & $12,8 \%$ & $35,9 \%$ & $51,3 \%$ & $100 \%$ \\
\hline \multirow[t]{2}{*}{ Outgoing personality } & Count & 6 & 11 & 10 & 14 & 41 \\
\hline & $\%$ & $14,6 \%$ & $26,8 \%$ & $24,4 \%$ & $34,1 \%$ & $100 \%$ \\
\hline
\end{tabular}

\section{Competency profile}

The aim of this research project was to develop a competency framework that would assist in improving the skills and knowledge required in information literacy instruction. The reality is that many instruction librarians were placed, or found themselves in the instructional field because no one else wanted to teach information literacy, skills. Tuttle (200I:14I) maintains that "instruction librarians received little or no formal training in graduate school and they have learned and refined their teaching craft on the job." According to LaGuardia (200I:I), there is a substantial need for good library instruction in all libraries. LaGuardia asserts that "good library instruction can overcome flaws and faults in a library", and, points out that there are few publications specifically on the subject of how to put together a library information literacy program ..

Tuttle (200I:14l) asserts that for instruction librarians to become better teachers, there is a need for the writing and compiling of a competency portfolio. The competency portfolio would document the teaching performance. Tuttle maintains that over 400 institutions in the United States and Canada, have embraced the portfolio format because it produces a complete picture of a librarians teaching ability.

The library instruction-related initiatives cannot be successfully designed and implemented single-handedly. For the information literacy programs to be effective, the instruction librarian is expected to make contact and solicit support and contributions from various university stakeholders such as student bodies, academic departments, library peers and administrators (Research Scholarship Committee of ACRL's Instruction Section 2003: I I I). The expected familiarity from the instruction librarian with regard to the departments and campus formations, prompted the potential for developing an inventory of the minimum competencies..

A competency profile is recommended based on findings from both the literature review and the findings of the empirical study. These comprise of technical and non-technical competencies (see Table 4) associated with the knowledge and skill that can be used by instruction librarians for developmental purposes (Osika and Sharp 2002:3). The proposed competency profile can also be used by employers when designing a role profile for the instruction librarian 
position or job description. Library and Information Science schools may find the competency profile useful when redesigning the information literacy curriculum. Table 4 below summarises the proposed competencies, followed by a more detailed discussion:

Table 4 Competency profile: instruction librarian

\begin{tabular}{|c|c|}
\hline Technical competencies & Non-technical competencies \\
\hline Knowledge and understanding of presentation or training delivery & Interpersonal skills \\
\hline Knowledge and understanding of adult learning principles & Language skills \\
\hline Basic knowledge and understanding of teaching methodologies & Empathizing \\
\hline Basic knowledge and understanding of pedagogy & Service orientation \\
\hline Knowledge and understanding of learning styles & Results orientation \\
\hline Knowledge and understanding of scaffolding techniques & Organizing \\
\hline Knowledge and understanding of the university tuition policy & Sense of urgency \\
\hline Knowledge and understanding of the university teaching and learning strategy & Initiative \\
\hline Knowledge and understanding of information literacy standards & Collaborative \\
\hline Knowledge and understanding of information literacy competencies & Supportiveness \\
\hline Knowledge and understanding of the online learning environment & Logical reasoning \\
\hline Knowledge and understanding of learning outcomes & Analytical thinking \\
\hline Knowledge and understanding of the principles of content development and delivery & Assertiveness \\
\hline Knowledge and understanding of principles of conceptual mapping & Judgement \\
\hline Knowledge and understanding of course or learning design & Flexibility \\
\hline Knowledge and understanding of assessment techniques & Time management \\
\hline Knowledge and understanding of instructional devices & Ability to explain \\
\hline Knowledge and understanding of media formats/mode of delivery & Approachable \\
\hline Knowledge and understanding of resources in electronic format & Critical thought \\
\hline Knowledge and understanding of lesson planning & Conflict resolution \\
\hline Knowledge and understanding of presentation apparatus & Negotiation \\
\hline \multicolumn{2}{|l|}{ Intermediate level in use of office packages (e.g. word processor packages etc) } \\
\hline \multicolumn{2}{|l|}{ Basic knowledge and understanding of subject disciplines } \\
\hline \multicolumn{2}{|l|}{ Basic knowledge and understanding of project management principles } \\
\hline \multicolumn{2}{|l|}{ Collaboration management } \\
\hline Relationship management & \\
\hline
\end{tabular}

Proposed technical competencies in output and job content

The empirical survey indentified a number of competencies instruction librarians should have. The proposed job content is based on the minimum technical competencies information services may expect the instruction librarian to have in order to be able to establish focused training opportunities (Osika and Sharp 2002:5). The technical skills should ensure the following:

- The promotion of information literacy to the institution.

- The organizing of information literacy programs.

- The presentation of appropriate information literacy instruction skills.

- The course design and development of information literacy programs in collaboration with academic departments and learner developers.

- The continuous evaluation of information literacy programs in collaboration with academic departments and learner or curriculum developers.

- The design of policies and procedures governing the information literacy programs.

- The participation in the selection, evaluation and recommendation of information communication technologies to be used in instruction.

- The maintenance of internal and external relationships with stakeholders or partners impacting on information literacy instruction such as the student bodies, dean of student's office, peers at other universities, etc.

- To keep up to date with the e-learning environment and electronic resources.

- To keep up to date with the learning methodology and pedagogy.

Proposed behavioural indicators of non-technical competencies

According to Osika and Sharp (2002:7), technical competency is only one aspect required to be successful with information literacy instruction. Other aspects such as the behaviour, motivation, facilitation and requirements of the 
course need to be considered to fully understand the complex process of learning. The following non-technical competencies were derived both from findings of the survey and the literature review:

An interpersonal skill in information literacy instruction would require the instruction librarian to display approachable behaviour towards the students.

Having "Language skills" in information literacy instruction refers to a person who demonstrates sensitivity to other people's language preferences and understanding during instruction. The instruction librarian should act consistently in appropriate ways to accommodate language diversity (Howze and Moore 2003:59).

"Empathizing" in information literacy instruction includes understanding and communicating the students' thoughts, feelings, values and beliefs as students bring existing knowledge to the learning process.

"Service orientation" refers to the instruction librarian being able to provide help to students and to serve their information literacy needs over his or her own.

"Results orientation" refers to the ability of the instruction librarian to effectively present and deliver training that meets the information literacy standards and competencies for higher education, as stipulated by the ACRL (American College of Research Libraries) in 200I.

"Organizing" means that the instruction librarian as educator must be able to conceptualize and propose training ideas into workable tasks; structures tasks into logical processes and priorities tasks and resources according to the instruction plans.

"Sense of urgency" requires that instruction librarians should be able to prioritize training needs effectively, and should be able to meet and take accountability for making decisions about critical decisions. This includes being focused and disciplined.

"Initiative" requires that the instruction librarian is an independent thinker, is proactive instead of being reactive and is being driven by willingness to translate ideas into action. This non-technical competency is important as students expect a librarian to assume different roles when in training.

"Collaborative" is a key component, as instruction librarians are expected to demonstrate a willingness to share knowledge and establish good working relationships. This requires the person to be warm and friendly(Scales et al.2005:234).

"Logical reasoning", "critical thought", "analytical thinking" and "judgement" involve the ability to interpret and translate information literacy standards and competencies. Analytical thinking is important when using the reactive and proactive technique during instruction. The librarian must be able to follow up students who might have a problem understanding concepts (Ward 2001:924).

"Supportiveness" means that during instruction, instruction librarians should distance themselves from their own beliefs and prejudices towards the students. The instruction librarian should accommodate the individual differences in learning rates, attitudes and motivation levels (Winfield and Manning 1992:183).

The "Ability to explain" and "flexibility" include the manner in which information literacy content is explained to the students. This includes the use of terminology understood by the students and being able to explain in a language understandable to the students. The use of examples relevant to the student's background knowledge is important (Cloud 1993:63).

"Conflict resolution" and "negotiation skills" are important in order to ensure that training participation by students is fair for those students who cannot voice their opinions. Collins and Robin (2004:6) are of the opinion that students engage in academic procrastination because of library anxiety, consequently limiting their opportunities to develop appropriate skills..

"Assertiveness" in information literacy instruction involves the ability to express beliefs and opinions especially when involved in a collaborative relationship within the institution (Scales et al.2005:233).

\section{Conclusion}

In academic libraries, much has been said and written about how the Internet, for example, has affected the day-to-day work of librarians in areas such as reference and collection development, less has been said about how other organizational imperatives such as instruction help to redefine the role of information professionals in the academic library of the $21^{\text {st }}$ century.

The rise of information literacy instruction as a strategic direction for libraries require instruction librarians to act as leaders both within the library and across campus. They have the responsibility to effectively articulate a vision and systemic plan for instruction that will affect students' perceptions and performance during information literacy sessions. Instruction librarians are usually unaware of the range of challenges (cognitive and behavioural) they face in order to balance issues surrounding the design, development and promotion of instruction programmes. These challenges were 
discussed and a competency profile was proposed for implementation as a management tool for designing key performance areas of instruction librarians.

\section{References}

American College of Research Libraries. 200I. Information literacy competency standards for higher education. Available at: http://www.ala.org/ala/acrl/acrlstandards/informationliteracycompetency.htm. [Viewed August 22, 2004].

Cloud, N. 1993. Language, culture and disability: implications for instruction and teacher preparation. Teacher education and special education, 16(I): 60-72.

Collins, K.M.T and Robin, E.V. 2004. Off-campus adult learners levels of library anxiety as a predictor of attitudes toward the internet. Library and information science research, 26(I):5-14.

Available at: www.sciencedirect.com [Viewed July 15, 2005].

Contech, J. 2003. Succeeding in diversity culture, language and learning in primary classrooms. Staffordshire: Trentham Books.

Cudiner, S. \& Harmon, O. 200I. Comparing the effectiveness of different presentation formats for workshops on introductory library skills. Research strategies, 18: 49-6।.

De Jager, K. \& Nassimbeni, M. 2003. An exploration of the current status of information literacy tuition in South African tertiary institutions and proposals for curriculum design. South African journal of library and information science, 69(2): 108-II4.

Gunter, D.J. 200I. Breaking barriers and building boundaries: creating better instructional sessions in an environment of change. In: Nims, J.K. \& Andrew, A, eds. Library user education in the new millennium: blending tradition, trends and innovation. Ann Arbor, Michigan: Pierian Press: 91-98.

Hadaway, N.L. 1993. Teaching in the midst of diversity: how do we prepare? In: O'Hair, M.J. \& Odell, S.J., eds. Diversity and teaching teacher education yearbook I. Orlando: Harcourt Brace Jovanovich: 60-70.

Herrington, V.J. 1998. Way beyond BI: a look at the future. Journal of academic librarianship, 24(5): 38I-385.

Hinchliffe, L.J. 2002. Information literacy as a way of life. Research strategies, 18(2): 95-96.

Hope, C.B.; Kajinara, S. \& Liu, M. 200I. The impact of the internet: increasing the reference librarian's role as teacher. The reference librarian, 74: I3-36.

Howze, P.C and Moore,D.M. 2003. Measuring international students understanding of concepts relating to the use of librarybased technology. Research strategies . 19:57-74. Available at: www.sciencedirect.com [Viewed June 15,2004].

Inglis, A. 2003.Facilitating team-based course design with conceptual mapping. Distance education. 24(2), October: 247-263.

Johnson, C.M.; McCord, S.K. \& Walter, S. 2003. Instructional outreach across the curriculum: enhancing the liaison role at a research university. The reference librarian, 82: 19-37.

Kaufman, P. 2004. The fate of the undergraduate library: a place for all disciplines. Library journal, 25(|8): 38-4I.

Kibirige, H.M. \& DePalo, L. 200I. The education function in a digital library environment: a challenge for college and research libraries. Electronic library, 19(5): 283-295.

Kraemer, E.W.; Keyse, D.J. \& Lombardo, S.V. 2003. Beyond these walls: building a library outreach program at Oakland University. The reference librarian, 82: 5- 17.

LaGuardia, C. 200I. Deep in the heart of instruction: the new library teachers. In: Nims, J.K. \& Andrew, A, eds. Library user education in the new millennium: blending tradition, trends and innovation. Ann Arbor, Michigan: Pierian Press: I-I4.

Moore, K. \& Abson, C. 2002. Really useful or virtually useless? Update, I (8): 34-36.

Nations-Johnson, L. 1993. On becoming a responsive teacher: a self-observational process analysis. In: O'Hair, M.J. \& Odell, S.J., eds. Diversity and teaching teacher education yearbook I. Orlando: Harcourt Brace Jovanovich.

Oberman, C. 2002. What the ACRL institute for information literacy best practices initiative tells us about the librarian as teacher. 68 ${ }^{\text {th }}$ IFLA Council and General Conference, August 18-24,2002. Glasgow, Scotland. Available at http:// www.IFLA.org/IV/ifla68/prog 02.htm [Accessed August 26,2004]

Osika, E.R and Sharp, D.P. 2002. Minimum technical competencies for distance learning students. Journal of research on technology in education. Eugene:Spring, 34(3): 318 - 325. Available at http://proquest.umi.com/ [Viewed 5 November 2004].

Oswald, T.A. \& Turnage, M. 2000. First five minutes. Research strategies, 17: 347-35I.

Partello, P. 2005. Librarians in the classroom. The reference librarian, 43(89/90): 107-120. Available at http:// www.haworthpress.com/web/REF [Viewed April 2005.

Ren, W.H. 2000. Library instruction and college student self-efficacy in electronic information searching. Journal of academic librarianship, 26(5): 323-328.

Scales, J, Matthews, G and Johnson, C. M. 2005. Compliance, cooperation, collaboration and information literacy. The journal of academic librarianship. 3I (3), May: 229-235.

Small, R.V.; Zakaria, N. \& El-Figuigui, H. 2004. Motivational aspects of information literacy skills instruction in community college libraries. College and research libraries, 65(2): 96-121.

Stubley, P. 2002. Skills move to VLEs. Update, I(7): 34-35.

Stroyan, S. 2000. The fate of the undergraduate library. Students won't buy information. Library journal, 125(18): 38-4I.

Tenopir, C. 2003. Are online librarians teachers? Library journal, I28(6): 36.

Tuttle, J.P. 200I. Bringing the indivisible into focus: teaching portfolios for the instruction librarian. In: Nims, J.K. \& Andrew, A, eds. Library user education in the new millennium: blending tradition, trends and innovation. Ann Arbor, Michigan: Pierian Press: $14 \mid-149$.

Ward, D. 200I. The future of information literacy: transforming the world. College and research library news, October: 922-925.

Winfield, L.F and Manning, J.B. 1992. Changing school culture to accommodate student diversity. In: Diversity in teacher education new expectations. Edited by Dilworth, ME. San Franscisco: Jossey- Bass: $|8|-2 \mid 4$. 